\title{
Védőoltásokkal kapcsolatos kételyek és elkötelezettség a magyarországi egészségügyi alapellátásban dolgozók körében
}

\author{
Kun Eszter ${ }^{1}$ - Benedek Angéla dr. ${ }^{2}$ - Mészner Zsófia dr. ${ }^{3}$ \\ ${ }^{1}$ Szinapszis Piackutató és Tanácsadó Kft., Budapest-Debrecen \\ ${ }^{2}$ MSD Pharma Hungary Kft., Budapest \\ ${ }^{3}$ Dél-pesti Centrum Kórház, Hematológiai és Infektológiai Intézet, Védőoltási Szaktanácsadó, Budapest
}

\begin{abstract}
Bevezetés: Az Európai Betegségmegelőzési és Járványvédelmi Központ (European Centre for Disease Prevention and Control, ECDC) korábbi nemzetközi felmérése az egészségügyi dolgozók védőoltásokkal kapcsolatos fenntartásait, vakcinációs bizonytalanságát tárta fel.

Célkitüzés: A magyar alapellátásban dolgozó felnőtt-, vegyes és gyermek- (háziorvosi praxisban dolgozó) szakorvosok, valamint a védőnők védőoltásokkal kapcsolatos attitúdjeinek vizsgálata.

Módszer: Az egészségügyi szakemberek védőoltással kapcsolatos fenntartásait saját fejlesztésú kérdőívvel vizsgáltuk, amelynek alapjául az ECDC négy országos nemzetközi kutatása szolgált. Az adatfelvétel 2017 májusától júliusáig zajlott, online kérdőíves megkereséssel. A kérdőívet összesen 765 egészségügyi szakember: 189 házi gyermekorvos, 375 felnőtt-, illetve vegyes praxisú háziorvos, valamint 201 védőnő töltötte ki. A mintát a munkavégzés helyének régiója, településtípusa, valamint a szakember életkora szerint súlyozással igazítottuk az országos megoszláshoz az egyes szakmai csoportokon belül, így ezen szempontok mentén reprezentatívnak tekinthető.

Eredmények: Megállapítható volt, hogy a vizsgált témakörökben kapott válaszok nem különböztek érdemben az ECDC hasonló, más országokban talált eredményeitől. Az alapellátó orvosok mintegy 2/3-a, a védőnők fele van meggyőződve a védőoltások nyújtotta előnyökről és értékekről. Megnyugtatóan alacsony arányban vannak fenntartásaik a védőoltások biztonságosságát illetően, bár az ajánlott védőoltásoknál az értékek némileg magasabbak voltak az életkor szerint kötelezőkhöz - a Nemzeti Immunizációs Programban adott oltásokhoz - képest. A szakirodalomból is jól ismert kifejezett oltásellenes rémhírek - autizmus-MMR stb. - fellelhetốk ugyan, de elenyésző arányban, ám ez összefüggésben állhat a vizsgálatban való önkéntes részvétellel is. Az életkor szerint előírt oltások közül a leginkább elutasított a BCG-oltás, míg a legtöbb kétely az MMR-oltást övezi.

Következtetés: Az alapellátók védőoltásokkal kapcsolatos kommunikációs készségeinek fejlesztését szolgáló képzésekre igény van, mind a graduális, mind a posztgraduális stúdiumokban.

Orv Hetil. 2019; 160(48): 1904-1914.
\end{abstract}

Kulcsszavak: védőoltás-bizonytalanság, felmérés, házi gyermekorvos, háziorvos, védőnő

\section{Vaccine hesitancy among primary healthcare professionals in Hungary}

Introduction: The attitude to immunization and the issue of vaccine hesitancy in health care workers (HCWs) have been studied in a former survey performed by ECDC (European Centre for Disease Prevention and Control).

Aim: Our aim was to study the immunization attitude of primary care paediatricians, general practitioners and primary care nurses in Hungary.

Method: We studied vaccine hesitancy in HCWs by way of a questionnaire, developed on the basis of a recent similar survey by ECDC in four countries. The online survey has been performed between May and July 2017. Altogether 765 questionnaires have been returned: 189 primary care paediatricians, 375 general practitioners working in adult or mixed practices, and 201 primary care nurses. The sample has been weighted to the country-specific features $-e . g$., location of the practice, residence and age of the HCWs - within each of the three groups, so from this aspect it can be considered representative. 
Results: Our results did not differ substantially from the international ECDC data. Approximately $2 / 3$ of the primary care doctors and about $50 \%$ of the primary care nurses were convinced of the benefit and value of vaccines. Data on vaccine hesitancy were consolingly low, though the data on recommended vaccines were somewhat higher compared to the age related/NIP (National Immunization Plan) vaccines. The well-known vaccine scares - e.g., autismMMR, etc., known also from the literature - could hardly been detected, and it can be explained by the voluntary participation in the study. The least supported vaccine is BCG, while the highest hesitancy rates are related to MMR in Hungary.

Conclusion: The need to improve immunization-related communication among primary HCWs could clearly been detected - both in gradual and in post-gradual training programs.

Keywords: vaccine hesitancy, survey, primary care paediatrician, general practitioner, primary care nurse

Kun E, Benedek A, Mészner Zs. [Vaccine hesitancy among primary healthcare professionals in Hungary]. Orv Hetil. 2019; 160(48): 1904-1914

(Beérkezett: 2019. május 20.; elfogadva: 2019. július 22.)

\section{Rövidítések}

BCG $=$ Bacillus Calmette-Guérin; ECDC $=($ European Centre for Disease Prevention and Control) Európai Betegségmegelőzési és Járványvédelmi Központ; EIW = (European Immunization Week) Európai Védőoltási Hét; EMMI = Emberi Erőforrások Minisztériuma; HGYE = Házi Gyermekorvosok Egyesülete; HPV = humán papillomavírus; MAOTE = Magyar Általános Orvosok Tudományos Egyesülete; MAVE = Magyar Védőnők Egyesülete; MMR = morbilli (kanyaró)-mumpsz-rubeola; NNK = Nemzeti Népegészségügyi Központ; NUTS2 = (Nomenclature of Territorial Units for Statistics 2) statisztikai területi egységek-2; WHO $=$ (World Health Organization) Egészségügyi világszervezet

Az oltásokkal kapcsolatos fenntartások - közismert angol elnevezéssel „vaccine hesitancy” - összetett és gyorsan változó globális probléma. Az Egészségügyi világszervezet (World Health Organization, WHO) meghatározása szerint: „Oltási bizonytalanságon az oltások elfogadásának halogatását vagy az oltások visszautasítását értjük, amikor ez annak ellenére történik, hogy az oltóanyag és a beadási szolgáltatások rendelkezésre állnak. Az oltási bizonytalanság komplex és kontextusspecifikus jelenség, így az évek előrehaladtával, földrajzi elhelyezkedés és oltóanyagtípus szerint változó. Olyan tényezőket is magában foglal, mint a túlzott biztonságérzet, az elkényelmesedés és a magabiztosság” [1].

A felajánlott vakcináció elfogadása a gyakorlatban megfelel annak, hogy az EMMI módszertani levelében jelzett vakcinákat az oltandóknak milyen arányban sikerült beadni az adott oltási sémának megfelelően. Az ily módon képzett átoltottsági mutatószám jelzi az adott oltási program sikerét [2]. Az érem másik oldalát képviseli a vakcinációba vetett bizalom fogalma, mely szintén több tényezőből áll. Általánosan jellemzi a szülők/ egészségügyi szakemberek véleményét az egyes védőoltások indokoltságáról, magában foglalja a vakcinációt ajánló szakemberek tudását, valamint a védőoltás hatósági és járványügyi megalapozottságát [3]. Az előbbiektől eltérően azonban nehezen mérhető, illetve becsülhető mindennek hiánya az oltottak/nem oltottak körében [4].

Az emberek az egészségükkel kapcsolatos kérdésekben, így az oltások esetén is a leginkább az egészségügyi szakemberekben bíznak $[5,6]$. Ezért a WHO kifejezetten javasolja, hogy az országok folyamatosan monitorozzák az oltási bizonytalanság mértékét, így dolgozzanak ki előremutató, ún. „Bizalom Fenntartása a Védőoltásokban” projekttervet [1]. Az Európai Betegségmegelőzési és Járványvédelmi Központ (European Centre for Disease Prevention and Control, ECDC) 2015-ben „pilot" felmérést végzett négy országban, Romániában, Horvátországban, Görögországban, és Franciaországban, ahol több oltási program tekintetében alacsonynak bizonyult az átoltottság. A kb. 30 perces interjúk során a kérdéseket értékneutrálisan fogalmazták meg, hogy ne befolyásolják a válaszadókat. A felmérés kirajzolta, hogy a gazdasági-politikai krízis következtében Görögországban a vakcinák iránt is nagyfokú bizalmatlanság tapasztalható, ellentétben például Franciaországgal $[7,8]$.

A téma fontosságára utalva, az ECDC évente megrendezett Európai Védőoltási Hetének (European Immunization Week, EIW - ez évben 2018. április 23-29.) egyik fö üzenete a védőoltásokkal kapcsolatos félelmek és fenntartások kezelésének fontossága valamennyi országban.

Az ECDC által végzett felmérés módszertanát [7] alapul véve a jelen tanulmány az egészségügyi alapellátásban dolgozó szakemberek oltással kapcsolatos fenntartásait mérte Magyarországon. A kutatás mind tartalmi, mind módszertani szempontból előzmény nélküli, hazánkban hasonló, publikált kutatás eddig nem történt.

A kutatók félig strukturált interjúkat folytattak, és kérdőív segítségével országos reprezentatív mintán vizsgálták az oltási bizonytalanság mértékét és alapját olyan egészségügyi szakemberekkel, akik tanácsadói, gondozói munkakörben vannak gyermekek és felnőttek védőoltása kapcsán. 


\section{Módszer}

A kérdőívet védőoltási tanácsadó orvosból, kutató szociológusból és gyógyszeripari szakemberből álló munkacsoport dolgozta ki. A kérdőívet a kutatást segítő szakmai szervezetek, a Házi Gyermekorvosok Egyesülete (HGYE), a Magyar Általános Orvosok Tudományos Egyesülete (MAOTE) és a Magyar Védőnők Egyesülete (MAVE) segítségével validáltuk. Az online kérdőív önkéntes volt.

Az adatfelvétel 2017. május 8. és július 6. között zajlott a Magyarországon aktívan praktizáló házi gyermekorvosok, háziorvosok és védőnők körében egy 765 fős mintán. A kérdóívet 189 házi gyermekorvos, 375 felnőtt-, illetve vegyes praxisú háziorvos, valamint 201 védőnő töltötte ki. A minta a súlyozás után reprezentálja a 3 szakmai csoportot a munkavégzés régiója, településtípusa és a szakemberek életkora szerint (1. táblázat).

Az ECDC-kutatáshoz hasonlóan [7] a kérdéseket a 6 fó témakörbe csoportosítottuk. Foglalkoztunk az oltások nyújtotta előnyökkel és a biztonságosságukkal kapcsolatos aggodalmakkal. Kíváncsiak voltunk arra, milyen szerepük van a szakembereknek az oltandók/szüleik aggodalmainak kezelésében. Fontos kérdés a védőoltások beadásának időzítése, az előírt időpont halasztása, illetve az ajánlott oltások esetén az ajánlás elmulasztása. Megkérdeztük, hogy milyen mértékú a szakemberek bizalma az elérhető információforrásokban, illetve milyen tényezők befolyásolják döntéseiket. A kérdőív kialakításakor figyelembe vettük a magyar viszonyokat, különös tekintettel arra, hogy országunkban létezik a kötelező és ingyenes védőoltás fogalma. Mivel ezek beadására törvényi

1. táblázat A minta jellemzése

\begin{tabular}{|c|c|c|c|c|}
\hline & & $\begin{array}{c}\text { Felnőtt- } \\
\text { és vegyes } \\
\text { praxisú } \\
\text { háziorvosok }\end{array}$ & $\begin{array}{c}\text { Házi } \\
\text { gyermek- } \\
\text { orvosok }\end{array}$ & Védőnók \\
\hline Mintaelem & & 375 & 189 & 201 \\
\hline $\mathrm{Nem}$ & Férfi & $45 \%$ & $16 \%$ & $0 \%$ \\
\hline & Nő & $55 \%$ & $84 \%$ & $100 \%$ \\
\hline Életkor & 25-44 éves & $18 \%$ & $9 \%$ & $56 \%$ \\
\hline & 45-64 éves & $60 \%$ & $64 \%$ & $41 \%$ \\
\hline & 64 évnél idősebb & $22 \%$ & $27 \%$ & $3 \%$ \\
\hline A & Budapest & $15 \%$ & $21 \%$ & $15 \%$ \\
\hline $\begin{array}{l}\text { munka- } \\
\text { végzés }\end{array}$ & Megyeszékhely & $15 \%$ & $26 \%$ & $16 \%$ \\
\hline település- & Város & $28 \%$ & $43 \%$ & $33 \%$ \\
\hline típusa & Község & $42 \%$ & $10 \%$ & $36 \%$ \\
\hline $\begin{array}{l}\text { A } \\
\text { munka- }\end{array}$ & $\begin{array}{l}\text { Budapest és Pest } \\
\text { megye }\end{array}$ & $25 \%$ & $35 \%$ & $26 \%$ \\
\hline $\begin{array}{l}\text { végzés } \\
\text { régiója }\end{array}$ & $\begin{array}{l}\text { Kelet-Magyar- } \\
\text { ország }\end{array}$ & $42 \%$ & $37 \%$ & $43 \%$ \\
\hline & $\begin{array}{l}\text { Nyugat-Magyar- } \\
\text { ország }\end{array}$ & $33 \%$ & $28 \%$ & $31 \%$ \\
\hline
\end{tabular}

elóírások vonatkoznak, nem várható el, hogy elutasításukról vagy az abszolút oltásellenességről direkt kérdésekkel valós képet kapjunk. Ezért több nyitott kérdéssel jártuk körbe az aggályokat, fenntartásokat, valamint részletesen kérdeztük a szakembereket nemcsak saját gyakorlatukról, vélekedésükről, hanem a kollégáik körében tapasztaltakról is az oltások kapcsán - bízva abban, hogy a kutatás önkéntes és anonim volta megfelelő és biztonságos teret biztosít így a valós helyzet felméréséhez.

Célunk a nemzetközi kutatás által feltárt vélekedések meglétének, illetve hiányának megállapítása volt. A védőoltásokkal kapcsolatos attitüdcsoportok meghatározásához klaszterelemzést végeztünk. A vizsgált 3 szakmai csoport válaszainak eloszlása közötti szignifikáns eltéréseket 0,05 -ös szinten többmintás z-próba segítségével vizsgáltuk.

\section{Eredmények}

\section{A védöoltásnak tulajdonitott elönyök}

Oltások beadásából származó előnyök és kockázatok megítélése

A magyar szakemberek többsége egyetért abban, hogy fontos a védőoltásokba vetett bizalom emelése, illetve annak tudatosítása, hogy az oltások nyújtotta egészségügyi előnyök meghaladják a várható mellékhatások kockázatát. A házi gyermekorvosok 65\%-a, a háziorvosok 68\%-a és a védőnők 53\%-a úgy gondolja, hogy erre a jelenleginél nagyobb hangsúlyt kell fektetni. Az orvosok körében a védőnőknél nagyobb volt azok aránya, akik a magas átoltottság fenntartását is fontosnak látják.

\section{Az egyén és a közösség védelme (nyájvédelem)}

Megkérdeztük, vajon tájékoztatják-e a pácienseket, illetve szüleiket arról, hogy a védőoltás beadatása nemcsak az adott egyén számára, hanem mások védelme érdekében is fontos - és ha igen, ezt mely oltások kapcsán teszik (2. táblázat).

Azt találtuk, hogy a védőnők kiemelkedően magas arányban $(78 \%)$ tájékoztatják a szülőket a nyájvédelem jelentőségéről minden kötelező védőoltás kapcsán, ám csupán feleannyian (40\%) tesznek így az összes ajánlott, ám nem kötelező védőoltásnál. A házi gyermekorvosok a kötelező oltások esetén a védőnőknél kisebb (59\%), ajánlott védőoltás esetében nagyobb (52\%) arányban tájékoztatnak a nyájimmunitás jelentőségéről. A védőnőkhöz képest jóval több házi gyermekorvos csak bizonyos védőoltások kapcsán hívja fel az érintettek figyelmét azok össztársadalmi fontosságára (17 vs. 29\%). A háziorvosok ugyanakkor nem tesznek érdemi különbséget kötelező és ajánlott oltások között ebben a vonatkozásban (39\% vs. 32\%).

Azoktól, akik csupán bizonyos védőoltások kapcsán tájékoztatnak a nyájimmunitás jelentőségéről, megkérdeztük azt is, hogy melyek ezek a védőoltások. A házi gyermekorvosok az influenza elleni (20\%), a Meningococcusfertőzések elleni (15\%) és a bárányhimlő elleni (18\%) vé- 
2. táblázat |A közösség védelmének fontossága az oltás beadásakor folytatott beszélgetésekben

\begin{tabular}{|c|c|c|c|}
\hline $\begin{array}{l}\text { Kérdés: Volt olyan alkalom, amikor páciensének vagy szüleinek elmagyaráz- } \\
\text { ta, hogy a védőoltás beadatása nemcsak számára, hanem mások védelme } \\
\text { érdekében is fontos? (Több válasz jelölhető) }\end{array}$ & $\begin{array}{l}\text { Házi gyermekorvosok } \\
\qquad \mathrm{n}=189\end{array}$ & $\begin{array}{l}\text { Felnőtt- és vegyes } \\
\text { praxisú háziorvosok } \\
\qquad \mathrm{n}=375\end{array}$ & $\begin{array}{c}\text { Védőnők } \\
\mathrm{n}=201\end{array}$ \\
\hline Szignifikáns eltérések jelöléséhez az oszlopok megnevezése & A & $\mathrm{B}$ & $\mathrm{C}$ \\
\hline Az összes kötelező védőoltás esetén & $59 \%$ & $49 \%$ & $78 \%{ }^{\mathrm{AB}}$ \\
\hline Az összes ajánlott védőoltás esetén & $52 \%{ }^{\mathrm{B}}$ & $39 \%$ & $40 \%$ \\
\hline Csak bizonyos védőoltások esetén & $29 \%{ }^{\mathrm{C}}$ & $32 \%{ }^{\mathrm{C}}$ & $17 \%$ \\
\hline Nem & $3 \%$ & $6 \%$ & $3 \%$ \\
\hline
\end{tabular}

A 0,05-ös szinten szignifikáns eltéréseket (többmintás z-próba) abban az oszlopban jelöljük, amelyik szignifikánsan nagyobb, annak az oszlopnak a feltüntetésével, amelyikhez képest nagyobb.

dőoltásokat említették. A háziorvosok szintén az influenza elleni védőoltást említették a leginkább (27\%), ezt követte a hepatitis B-vírus okozta fertőző májgyulladás elleni (15\%), valamint a HPV és a Pneumococcusfertőzés elleni védőoltás (13-13\%). A védőnők egyedül az MMR-védőoltást említették számottevően (10\%). Míg a háziorvosok fóleg ajánlott védőoltásokat említettek, addig a védőnők az oltásellenesek által a legrégebben támadott MMR-t jelölték meg, mellyel kapcsolatban még azok is tájékoztatnak a nyájimmunitás jelentőségéről, akik más esetben erre nem fektetnek hangsúlyt.

\section{A védöoltásokkal kapcsolatos ismeretanyag megalapozottsága}

Kíváncsiak voltunk arra, hogy a magyar szakemberek mennyire fogadják el az oltásokról rendelkezésre álló tudományos bizonyítékokat. Erre abból következtethe- tünk, hogy milyen kétségeket és szakmai vitákat említettek, amikor megkérdeztük, hogy nekik maguknak milyen aggályaik vannak oltásokkal kapcsolatban, illetve hogy kollégáikkal voltak-e szakmai nézeteltéréseik oltások kapcsán.

Az orvosok többségének volt már kollégákkal szakmai vitája oltásokról (házi gyermekorvos: 70\%, háziorvos: $58 \%$ ), míg ez a védőnők csupán alig több mint 1/3-ára volt igaz. Érdekes, hogy e vitákban a házi gyermekorvosok alig több mint egyötöde (23\%), a háziorvosok még kisebb hányada (15\%) érvelt a védőoltások mellett, ám ez még mindig meghaladta a védőnők válaszait. Az orvosok még így is szignifikánsan nagyobb arányban érveltek oltások mellett, akár általánosságban, akár egy konkrét oltás kapcsán, mint a védőnők.

Az oltások időzítésének vitatása, későbbi időpontra halasztása a házi gyermekorvosi praxisokban fordul elő inkább, a háziorvosok és a védőnők szerint ritkán adódik ilyen (3. táblázat).

3. táblázat | Kollégák közötti szakmai viták előfordulása az oltások kapcsán

\begin{tabular}{|c|c|c|c|}
\hline & $\begin{array}{l}\text { Házi gyermekorvosok } \\
\qquad \mathrm{n}=189\end{array}$ & $\begin{array}{l}\text { Felnőtt- és vegyes } \\
\text { praxisú háziorvosok } \\
\qquad \mathrm{n}=375\end{array}$ & $\begin{array}{c}\text { Védőnők } \\
\mathrm{n}=201\end{array}$ \\
\hline Szignifikáns eltérések jelöléséhez az oszlopok megnevezése & A & B & $\mathrm{C}$ \\
\hline \multicolumn{4}{|c|}{ Előfordult már Önnel, hogy nem értett egyet kollégái álláspontjával a védőoltásokkal kapcsolatban? (Nyitott kérdés) } \\
\hline Nem & $30 \%$ & $42 \%{ }^{\mathrm{A}}$ & $64 \%^{\mathrm{AB}}$ \\
\hline \multicolumn{4}{|l|}{ Igen, mégpedig: } \\
\hline A védőoltások mellett érveltem & $23 \%{ }^{\mathrm{BC}}$ & $15 \%{ }^{\mathrm{C}}$ & $4 \%$ \\
\hline Egy konkrét oltás mellett érveltem & $11 \% \mathrm{C}$ & $7 \% \mathrm{C}$ & $4 \%$ \\
\hline A védőoltások ellen érveltem & $0 \%$ & $1 \%$ & $3 \% \mathrm{AB}$ \\
\hline Konkrét oltás kapcsán vitatkoztunk & $6 \%$ & $8 \%$ & $11 \%{ }^{\mathrm{A}}$ \\
\hline A védőoltásról általánosságban vitatkoztunk & $11 \%$ & $17 \%{ }^{\mathrm{AC}}$ & $8 \%$ \\
\hline Védőoltás beadásának időzítésével kapcsolatban vitatkoztunk & $12 \%{ }^{\mathrm{BC}}$ & $4 \%$ & $2 \%$ \\
\hline Ajánlott védőoltások kapcsán vitatkoztunk & $8 \%{ }^{\mathrm{BC}}$ & $4 \%^{\mathrm{C}}$ & $1 \%$ \\
\hline Egyéb & $8 \%{ }^{\mathrm{BC}}$ & $2 \%$ & $0 \%$ \\
\hline Nem válaszolt & $0 \%$ & $3 \%{ }^{\mathrm{A}}$ & $3 \%^{\mathrm{A}}$ \\
\hline
\end{tabular}

A 0,05-ös szinten szignifikáns eltéréseket (többmintás z-próba) abban az oszlopban jelöljük, amelyik szignifikánsan nagyobb, annak az oszlopnak a feltüntetésével, amelyikhez képest nagyobb. 
4. táblázat |A páciensek számára ajánlott nem kötelező oltások

\begin{tabular}{|c|c|c|c|}
\hline $\begin{array}{l}\text { Kérdés: Melyek azok a nem kötelező védőoltások, amelyeket ajánl } \\
\text { pácienseinek? }\end{array}$ & $\begin{array}{l}\text { Házi gyermekorvosok } \\
\qquad \mathrm{n}=189\end{array}$ & $\begin{array}{l}\text { Felnőtt- és vegyes } \\
\text { praxisú háziorvosok } \\
\mathrm{n}=375\end{array}$ & $\begin{array}{l}\text { Védőnók } \\
\mathrm{n}=201\end{array}$ \\
\hline Szignifikáns eltérések jelöléséhez az oszlopok megnevezése & A & B & $\mathrm{C}$ \\
\hline $\begin{array}{l}\text { Kullancsencephalitis (kullancs által terjesztett vírusos agyvelőgyulla- } \\
\text { dás) elleni védőoltás }\end{array}$ & $95 \%$ C & $90 \%{ }^{\mathrm{C}}$ & $77 \%$ \\
\hline $\begin{array}{l}\text { Meningococcus-fertőzések (agyhártyagyulladás, vérmérgezés) elleni } \\
\text { védőoltás }\end{array}$ & $99 \%$ ВС & $76 \%$ & $82 \%$ \\
\hline HPV elleni védőoltás & $91 \% \mathrm{BC}$ & $77 \%$ & $74 \%$ \\
\hline Pneumococcus-fertôzés elleni védőoltás & $77 \%^{\mathrm{C}}$ & $89 \%$ & $56 \%$ \\
\hline Influenza elleni védőoltás & $71 \%^{\mathrm{C}}$ & $93 \%{ }^{\mathrm{AC}}$ & $34 \%$ \\
\hline Bárányhimlő elleni védőoltás & $93 \%^{\mathrm{BC}}$ & $39 \%$ & $60 \%^{\mathrm{B}}$ \\
\hline Rotavírus-fertőzés elleni védőoltás & $91 \%{ }^{\mathrm{BC}}$ & $35 \%$ & $46 \%^{\mathrm{B}}$ \\
\hline Hepatitis A (fertőző májgyulladás) elleni védőoltás & $53 \%{ }^{\mathrm{C}}$ & $61 \%{ }^{\mathrm{C}}$ & $19 \%$ \\
\hline
\end{tabular}

A 0,05-ös szinten szignifikáns eltéréseket (többmintás z-próba) abban az oszlopban jelöljük, amelyik szignifikánsan nagyobb, annak az oszlopnak a feltüntetésével, amelyikhez képest nagyobb.

Konkrét védőoltás kapcsán nagyon kis arányban kérdőjelezték meg az oltások tudományos hátterét. A válaszok 1-3\%-ában jött szóba az MMR-oltás és az autizmus, a szezonális influenza elleni, a méhnyakrák megelőzésére bevezetett HPV vagy a rotavírus-fertőzés elleni védőoltás tudományos megalapozottságában kétely. A HPV kapcsán viszont pozitív irányban a házi gyermekorvosok 5\%-a próbálta meggyőzni kollégáit az oltás beadásáról - ami rejtett fenntartások meglétére utalhat, hiszen expliciten jóval kisebb arányban jeleztek ilyet.

Indirekt, de erốs bizonyitéka az oltásokba vetett általános bizalom magas fokának az egészségügyi szakemberek között a nem kötelezó védöoltások ajánlása. 8 fertőző betegség kapcsán vizsgáltuk az ajánlási hajlandóságot (4. táblázat). A védőnők minden egyes, nem kötelező védőoltás ajánlását szignifikánsan kisebb arányban említik, mint a házi gyermekorvosok. Különösen nagy az eltérés a rotavírus ( 45 százalékpont), az influenza (37 százalékpont), a hepatitis A (34 százalékpont) és a bárányhimlő (32\%) elleni védőoltás esetében.

\section{Az oltások biztonságosságával kapcsolatos aggodalmak}

Általában az oltások mellékhatásait, mint gondot, a magyar szakemberek közel 2/3-a tartja fontosnak (házi gyermekorvosok: $62 \%$, felnőtt- és vegyes praxisban dolgozó háziorvosok: 70\%, védőnők: 69\%). Elsősorban a ritka, de súlyos mellékhatásoktól fél az orvosok 1/3-a, a védőnők 40\%-a. Lényegesen kevésbé találják aggasztónak a gyakori, enyhe mellékhatásokat - ezek csak az orvosok 9\%-át, a védőnők 16\%-át aggasztják.

Összességében nem magas a konkrét védőoltások mellékhatásprofiljával kapcsolatos fenntartások aránya a kötelező védőoltások kapcsán (a házi gyermekorvosok $7 \%$-a, a háziorvosok 3\%-a és a védőnők 8\%-a). A házi gyermekorvosok a BCG- (4\%), a védőnók az MMR(5\%), a háziorvosok a HPV-oltást (2\%) említették.

$\mathrm{Az}$ ajánlott védőoltásoktól többen tartanak ugyan, mint a kötelezőktől, de konkrét védőoltásra kérdezve mégis nagyon kevesen említik a mellékhatásokat, inkább a védettség tartamát (például HPV-oltás) kérdőjelezik meg. A gyermekorvosok ötöde, a háziorvosok 11\%-a, míg a védőnők közel 1/3-a (30\%) fejez ki aggodalmat ajánlott oltás biztonságosságával kapcsolatban. A házi gyermekorvosok leginkább az influenza- (11\%), a rotavírus- (7\%) és a Meningococcus- (6\%) fertőzések elleni védőoltásoktól tartanak. A háziorvosok érdemi számban csak az influenza elleni oltásról jeleztek kételyeket (7\%). A legnagyobb arányban a védőnóknek voltak aggodalmaik: $20 \%$ a HPV, 15\% az influenza, 11\% a bárányhimlő és $9 \%$ a rotavírus elleni védőoltás miatt aggódik.

\section{Az egészségügyi szakemberek szerepe a páciensek aggodalmainak megválaszolásában}

A magyar kérdőívben több oldalról jártuk körbe a páciensek/szüleik informálását, aggodalmaik megválaszolását: kérdeztük őket a munkahelyükön történő információszolgáltatásról, az elérhető beteginformáló anyagokról, a páciensek által említett információs forrásokról, a kollégák tájékoztatásra szánt idejéról. Igyekeztünk még a látszatát is kerülni annak, hogy a kutatás során bármifajta „számonkérés” zajlik.

A megkérdezett szakemberek több mint 2/3-a szerint nagyobb hangsúlyt kellene fektetniük az egészségügyi szakembereknek a páciensek aggályaira koncentráló kommunikációs ismeretekre. Míg a háziorvosok alig több mint fele gondolja, hogy kollégái elegendö idôt szánnak a védőoltásokkal kapcsolatos információk átadására és a páciensek kérdéseinek megválaszolására (házi gyermekorvosok: 54\%, háziorvosok: 56\%), addig a védőnők jóval nagyobb hányada, 84\%-a vélekedik így. 
5. táblázat |Az oltásokról szóló tájékoztató anyagok megítélése az adott szakember munkahelyén

\begin{tabular}{|c|c|c|c|}
\hline & $\begin{array}{l}\text { Házi gyermekorvosok } \\
\qquad \mathrm{n}=189\end{array}$ & $\begin{array}{l}\text { Felnőtt- és vegyes } \\
\text { praxisú háziorvosok } \\
\mathrm{n}=375\end{array}$ & $\begin{array}{l}\text { Védőnők } \\
\mathrm{n}=201\end{array}$ \\
\hline Szignifikáns eltérések jelöléséhez az oszlopok megnevezése & A & B & $\mathrm{C}$ \\
\hline \multicolumn{4}{|c|}{ Mit gondol, az Ön munkahelye elegendő információt és tanácsot ad a pácienseknek a védőoltásokkal kapcsolatban? } \\
\hline Igen & $89 \%{ }^{\mathrm{B}}$ & $79 \%$ & $92 \%{ }^{\mathrm{B}}$ \\
\hline Nem & $11 \%$ & $21 \%{ }^{\mathrm{AC}}$ & $8 \%$ \\
\hline \multicolumn{4}{|c|}{ Milyen információs anyagok érhetők el a páciensek számára az Ön munkahelyén a védőoltásokkal kapcsolatban? } \\
\hline Nyomtatott tájékoztató & $95 \%$ & $92 \%$ & $98 \%{ }^{\mathrm{B}}$ \\
\hline Weboldal (rendelö, intézmény, település) & $31 \%{ }^{\mathrm{B}}$ & $19 \%$ & $22 \%$ \\
\hline Egyéb & $21 \%$ & $14 \%$ & $12 \%$ \\
\hline \multicolumn{4}{|c|}{$\begin{array}{l}\text { Tapasztalatai szerint milyen információs anyagokra hivatkoznak a páciensei a védőoltásokkal kapcsolatban, amikor felkeresik Önt esetlege } \\
\text { aggályaikkal kapcsolatban? }\end{array}$} \\
\hline Nyomtatott tájékoztató & $24 \%$ & $37 \%{ }^{\mathrm{A}}$ & $31 \%$ \\
\hline Weboldal (rendelö, intézmény, település) & $58 \%$ & $55 \%$ & $52 \%$ \\
\hline Egyéb & $52 \%{ }^{\mathrm{B}}$ & $41 \%$ & $45 \%$ \\
\hline
\end{tabular}

A 0,05-ös szinten szignifikáns eltéréseket (többmintás z-próba) abban az oszlopban jelöljük, amelyik szignifikánsan nagyobb, annak az oszlopnak a feltüntetésével, amelyikhez képest nagyobb.

6. táblázat | Az oltást nem ajánló vagy oltást ellenző szakemberek véleménye

\begin{tabular}{|c|c|c|c|}
\hline & $\begin{array}{l}\text { Házi gyermekorvosok } \\
\qquad \mathrm{n}=189\end{array}$ & $\begin{array}{l}\text { Felnőtt- és vegyes } \\
\text { praxisú háziorvosok } \\
\qquad \mathrm{n}=375\end{array}$ & $\begin{array}{l}\text { Védönők } \\
\mathrm{n}=201\end{array}$ \\
\hline Szignifikáns eltérések jelöléséhez az oszlopok megnevezése & A & B & $\mathrm{C}$ \\
\hline \multicolumn{4}{|c|}{ Van Önnek olyan munkatársa, aki az Ön tudomása szerint nem támogatja egy vagy több védőoltás beadását? } \\
\hline Nem & $50 \%$ & $59 \%$ & $68 \%^{\mathrm{A}}$ \\
\hline Igen, kötelező védőoltás beadatását nem támogatja & $8 \%{ }^{\mathrm{C}}$ & $9 \%^{\mathrm{C}}$ & $2 \%$ \\
\hline Igen, ajánlott védőoltás beadatását nem támogatja & $50 \%^{\mathrm{BC}}$ & $39 \%$ & $32 \%$ \\
\hline \multicolumn{4}{|c|}{$\begin{array}{l}\text { Van-e a Nemzeti Népegészségügyi Központ módszertani levelében felsorolt kötelező vagy választható védőoltások között olyan, amit nem tart } \\
\text { szükségesnek? }\end{array}$} \\
\hline Minden védőoltás szükséges & $74 \%^{\mathrm{C}}$ & $76 \%{ }^{\mathrm{C}}$ & $58 \%$ \\
\hline Valamelyik kötelező védőoltás nem szükséges & $10 \%^{\mathrm{B}}$ & $2 \%$ & $4 \%$ \\
\hline Valamelyik ajánlott védőoltás nem szükséges & $15 \%$ & $20 \%$ & $38 \%^{\mathrm{BA}}$ \\
\hline
\end{tabular}

A 0,05-ös szinten szignifikáns eltéréseket (többmintás z-próba) abban az oszlopban jelöljük, amelyik szignifikánsan nagyobb, annak az oszlopnak a feltüntetésével, amelyikhez képest nagyobb.

Majdnem az összes válaszadó munkahelyén elérhetők nyomtatott szakmai és lakossági tájékoztató anyagok, viszont mindössze a házi gyermekorvosok 1/3-a és az egyéb szakemberek 1/5-e számolt be olyan weboldalról, amely ezt a célt szolgálja. Ezzel szemben mindhárom szakmai csoport jelezte, hogy a hozzájuk forduló betegek több mint fele webes forrásokra hivatkozott, és mindössze $1 / 4-1 / 3$ részük nyomtatott tájékoztató anyagra, amikor kérdéseket tett fel vagy aggodalmairól számolt be (5. táblázat).

Az oltások ajánlásának elmulasztása, késleltetés Megkérdeztük, hogy van-e olyan védőoltás, amelynek beadását nem tartják szükségesnek, illetve hogy tudnak-e olyan kollégájukról, aki nem támogatja valamelyik védőoltás beadását.

A bázi gyermekorvosok felének van olyan kollégája, aki valamelyik ajánlott védőoltás beadását nem támogatja míg csupán $15 \%$ nem tartja valamelyiket szükségesnek: a legnagyobb arányban az influenza $(8 \%)$ és a rotavírus (7\%) elleni védőoltást. A kötelező védőoltások kapcsán fordított a viszony, bár igen kicsi a különbség: 8\%-uknak van olyan kollégája, aki nem támogatja valamelyik kötelező védőoltást, és 10\% maga gondolja így: főleg (8\%) a BCG-oltást említve (6. táblázat).

A háziorvosok 39\%-ának van olyan kollégája, aki valamelyik ajánlott védőoltás beadását nem támogatja - míg csupán 20\% nem tartja valamelyiket szükségesnek: a leg- 
7. táblázat |A védőoltásokkal kapcsolatos ellenvélemény megosztása

\begin{tabular}{lcc}
\hline $\begin{array}{l}\text { Kérdés: Próbálta Ön megosztani saját véleményét azzal a munkatársával, } \\
\text { aki nem támogatja egy vagy több védőoltás beadatását? }\end{array}$ & $\begin{array}{c}\text { Házi gyermekorvosok } \\
\mathrm{n}=95\end{array}$ & $\begin{array}{c}\text { Felnőtt- és vegyes } \\
\text { praxisú háziorvosok } \\
\mathrm{n}=155\end{array}$ \\
\hline Szignifikáns eltérések jelöléséhez az oszlopok megnevezése & $\mathrm{A}$ & $\begin{array}{c}\text { Védőnők } \\
\mathrm{n}=64\end{array}$ \\
\hline Igen & $69 \%$ & $73 \%$ \\
\hline Nem & $31 \%$ & $27 \%$ \\
\hline
\end{tabular}

A 0,05-ös szinten szignifikáns eltéréseket (többmintás z-próba) abban az oszlopban jelöljük, amelyik szignifikánsan nagyobb, annak az oszlopnak a feltüntetésével, amelyikhez képest nagyobb.

nagyobb arányban a bárányhimlő (10\%) és a rotavírus (8\%) elleni védőoltást. A kötelező védőoltások kapcsán 9\%-uk jelezte, hogy van olyan kollégája, aki nem támogatja valamelyik kötelező védőoltást, és mindössze $2 \%$ gondolja így maga is.

A védönők 1/3-ának van olyan kollégája, aki valamelyik ajánlott védőoltás beadását nem támogatja - ezzel szemben 38\% maga nem tartja szükségesnek valamelyiket: a legnagyobb arányban az influenza (16\%), a rotavírus (15\%), a bárányhimlő (13\%) és a hepatitis A (11\%) elleni védőoltást. A kötelező védőoltások kapcsán is hasonló arányaiban az eredmény, bár igen kicsi a különbség (2-4\% közötti) (6. táblázat).

Fontosnak tartjuk itt megjegyezni, hogy amikor a kollégákkal az oltások kapcsán meglévő véleménykülönbségekről érdeklődtünk, néhányan aggasztó jelenségről is beszámoltak a kötelezó védöoltások kapcsán. Említettek kollégát, aki a szülő kérésére a kötelező oltást nem adja be, de dokumentálja - a matricát az oltási könyvbe beragasztja. Egyes kollégák homeopátiás gyógymódokkal helyettesítik a védőoltásokat. Az ilyen típusú válaszok száma azonban összességében nem érte el az 1\%-ot.

Észlelhető mértékben megjelentek viszont a nemzetközi kutatásban is jelzett késleltetések, egyéni problémakezelési tervek (a házi gyermekorvosok 12\%-a, a felnőttés vegyes praxisban dolgozó háziorvosok 4\%-a, a védőnők $2 \%$-a bonyolódott ilyen témájú szakmai vitába).

Biztató, hogy azoknak a több mint 2/3-a, akiknek a munkatársa nem támogatja egy vagy több védőoltás beadását, megosztotta ezen kollégával a saját, támogató véleményét, azaz tudatosan vállalja szakmai felelősségét (7. táblázat).

\section{A védöoltásokról szóló döntés meghatározó tényezôi}

Az egészségügyi szakembereknek az oltásokról szóló információkba, illetve az információs forrásokba vetett bizalmát számos kérdéssel jártuk körbe. A járványügyi hatóságról kérdeztük őket, nevesítve a Nemzeti Népegészségügyi Központ (NNK) évente kiadott módszertani levelét. Elmondhatjuk, hogy az orvosok közel 2/3-a egyetért abban, hogy az egészségügyi dolgozók körében nagyobb hangsúlyt kellene fektetni a módszertani levélben felsorolt kötelező vagy ajánlott oltással történő átol- tottság fontosságának tudatosítására. A védőnők szignifikánsan kisebb arányban (38\%) értettek egyet ezzel az állítással. Ez különösen érdekes annak fényében, hogy mindhárom szakmai csoportnak közel a 9/10-e állította, hogy a védőoltások kapcsán megbízik a járványügyi hatóságban, és az elmúlt 1 évben igénybe is vette azt mint információs forrást (házi gyermekorvosok: 92\%, háziorvosok: $87 \%$, védőnók: 94\%) (8. táblázat).

A házi gyermekorvosok $1 / 3$-a, a háziorvosok 17\%-a és a védőnők mindössze 11\%-a bízik meg információs forrásként a gyógyszergyári látogatóktól kapott anyagokban, szakmai honlapokban, hivatalos e-mailekben, és ezeket igénybe is vették az elmúlt egy évben.

A különböző szakmai forrásokat típusok szerint csoportokba soroltuk, hogy a különböző információs csa-

8. táblázat |A védőoltásokkal kapcsolatos információforrások igénybevétele

\begin{tabular}{|c|c|c|c|}
\hline $\begin{array}{l}\text { Kérdés: Amikor információkat keres } \\
\text { a védőoltásokkal kapcsolatban, } \\
\text { melyik az a forrás, amelyben } \\
\text { megbízik, és amelyet az elmúlt } 1 \\
\text { évben igénybe is vett? }\end{array}$ & $\begin{array}{l}\text { Házi } \\
\text { gyermek- } \\
\text { orvosok } \\
\mathrm{n}=189\end{array}$ & $\begin{array}{l}\text { Felnőtt- } \\
\text { és vegyes } \\
\text { praxisú } \\
\text { házi- } \\
\text { orvosok } \\
\mathrm{n}=375\end{array}$ & $\begin{array}{l}\text { Védőnők } \\
\mathrm{n}=201\end{array}$ \\
\hline $\begin{array}{l}\text { Szignifikáns eltérések jelöléséhez az } \\
\text { oszlopok megnevezése }\end{array}$ & A & B & C \\
\hline Járványügyi hatóságok & $92 \%$ & $87 \%$ & $94 \%{ }^{\mathrm{B}}$ \\
\hline $\begin{array}{l}\text { Tradicionális szakmai forrásokból } \\
\text { - Konferencián hallott előadások } \\
\text { - Nyomtatott orvosi folyóiratok } \\
\text { - Gyógyszergyári látogatók }\end{array}$ & $96 \%^{\mathrm{BC}}$ & $84 \%$ & $85 \%$ \\
\hline $\begin{array}{l}\text { Digitális szakmai forrásokból } \\
\text { - Online orvosi folyóiratok } \\
\text { - Zárt orvosi portálok } \\
\text { - Egészségügyi szakemberek } \\
\text { számára készült weboldalak } \\
\text { - Gyógyszergyári honlapok, } \\
\text { e-mailek }\end{array}$ & $84 \%^{\mathrm{C}}$ & $77 \%{ }^{\mathrm{C}}$ & $51 \%$ \\
\hline $\begin{array}{l}\text { Közvetlen tapasztalat } \\
\text { - Saját tapasztalat } \\
\text { - Kollégák tapasztalatai, } \\
\text { véleménye } \\
\text { - (Védónók) Praxist vezető } \\
\text { orvossal egyeztet }\end{array}$ & $66 \%$ & $62 \%$ & $70 \%$ \\
\hline
\end{tabular}

A 0,05-ös szinten szignifikáns eltéréseket (többmintás z-próba) abban az oszlopban jelöljük, amelyik szignifikánsan nagyobb, annak az oszlopnak a feltüntetésével, amelyikhez képest nagyobb. 


\begin{tabular}{|c|c|c|c|}
\hline & $\begin{array}{l}\text { Házi gyermekorvosok } \\
\qquad \mathrm{n}=189\end{array}$ & $\begin{array}{l}\text { Felnőtt- és vegyes } \\
\text { praxisú háziorvosok } \\
\qquad \mathrm{n}=375\end{array}$ & $\begin{array}{l}\text { Védönők } \\
\mathrm{n}=201\end{array}$ \\
\hline Szignifikáns eltérések jelöléséhez az oszlopok megnevezése & A & $\mathrm{B}$ & $\mathrm{C}$ \\
\hline Nem tart szükségszerűnek minden ajánlott védőoltást & $11 \%$ & $19 \%$ & $26 \%{ }^{\mathrm{A}}$ \\
\hline $\begin{array}{l}\text { Leginkább az ajánlott védőoltásokkal szemben van aggálya, és ezek } \\
\text { mindegyikének szükségszerúségéről sincs meggyőződve }\end{array}$ & $11 \%{ }^{\mathrm{B}}$ & $3 \%$ & $22 \%{ }^{\mathrm{BC}}$ \\
\hline Szinte aggályok nélküli attitűddel rendelkezik & $78 \% \mathrm{C}$ & $78 \%{ }^{\mathrm{C}}$ & $52 \%$ \\
\hline
\end{tabular}

A 0,05-ös szinten szignifikáns eltéréseket (többmintás z-próba) abban az oszlopban jelöljük, amelyik szignifikánsan nagyobb, annak az oszlopnak a feltüntetésével, amelyikhez képest nagyobb.

tornák megbízhatóságát és igénybevételét kumuláltan vizsgálhassuk. A járványügyi hatóságokat nem soroltuk be egyik típusba sem - ezt említették minden szakmai csoportban a legtöbben, valamint szabályozószerepénél fogva sem tekinthető a többi forráshoz teljes mértékben hasonlónak. A magyar egészségügyi szakemberek a legnagyobb arányban a tradicionális szakmai forrásokban bíznak, és igénybe is vették őket az elmúlt évben. Ezt követik a digitális szakmai források, végül a közvetlen tapasztalatok - kivéve a védőnőket, akik körében a közvetlen tapasztalat nagyobb súlyt kap, mint a digitális szakmai források. A közvetlen tapasztalatok közül a páciensek kételyei, aggodalmai azonban a szakemberek saját bevallása szerint nagyon kis arányban befolyásolják a válaszadókat: a házi gyermekorvosok 6\%-át, a háziorvosok és a védőnők 3-3\%-át. Pedig nem ritka, hogy egy páciens ellenérzéseivel szemben kell saját szakmai véleményüket kinyilvánítaniuk: a vizsgálatba vont szakemberek mindössze 1/10-e állította, hogy ilyen nem fordult még elő vele. Azt a helyzetet, amikor szakmai véleményüket a páciens ellenérzéseivel szemben kell kinyilvánítaniuk, többnyire nem érzik kellemetlennek. Egy 5 fokú skálán - 1-es érték: „egyáltalán nem éreztem magam kényelmetlenül”, 5-ös érték: „nagyon kényelmetlenül éreztem magam" - az átlagérték a házi gyermekorvosok körében 1,81, a háziorvosok körében 1,75, a védőnők körében 2,16 volt, azaz a páciensek aggodalmai és véleménye kismértékben van hatással a vélekedésükre.

\section{A védöoltásokkal kapcsolatos attitüdcsoportok}

A védőoltásokkal kapcsolatos attitüdcsoportok meghatározásához klaszterelemzést végeztünk. Kétértékű (igennem) változókat vontunk be. A létrejött klaszter a következő csoportokat eredményezte:

A) Nem tart fontosnak minden ajánlott védőoltást.

B) Az ajánlott védőoltásokkal szemben van aggálya, és mindegyik létjogosultságáról nincs meggyőződve.

C) Szinte aggályok nélküli attitűddel rendelkezik.

Az eredmények szerint a védőnők körében a legmagasabb az oltási bizonytalanság A többség a jelenleg valóban szakmai viták tárgyát képező BCG-oltást jelölte meg (9. táblázat).

\section{Regionális eltérések egyes védöoltások megitéléséröl}

A regionális eltérések vizsgálatakor a Nomenclature of Territorial Units for Statistics 2-es szintű (NUTS2) régiókat alkalmaztuk (http://www.terport.hu/europaiunio/teruleti-szintek). Sok esetben igen alacsony elemszámú almintákat kellett összehasonlítanunk (10. táblázat).

A szakemberek között találtunk néhány nehezen értelmezhető eltérést, melyek részletezésétől - jelentőségük hiányában - eltekintünk.

\section{Megbeszélés}

Az oltásokkal kapcsolatos fenntartások összetett és gyorsan változó globális problémakörét azért az egészségügyi szakemberek körében vizsgáltuk, mert az emberek az egészségükkel kapcsolatos kérdésekben, így az oltások esetén is, még jelenleg is leginkább e szakemberek véleményében bíznak [5]. A hazai viszonyokhoz adaptált kérdőívhez az ECDC-kutatás [7, 8] szolgált mintaként három szakembercsoport, a házi gyermekorvosok, a háziorvosok és a védőnők bevonására.

Az oltások beadásából származó elönyök és kockázatok megitélése közel hasonló a bevont csoportokban, és a többség egyetért abban, hogy fontos a védőoltásokba

10. táblázat |A NUTS2-régiók szerinti alminták elemszámai

\begin{tabular}{lccc}
\hline & $\begin{array}{c}\text { Házi } \\
\text { gyermek- } \\
\text { orvosok } \\
\mathrm{n}=189\end{array}$ & $\begin{array}{c}\text { Felnőtt- és } \\
\text { vegyes } \\
\text { praxisú } \\
\text { háziorvosok } \\
\mathrm{n}=375\end{array}$ & $\begin{array}{c}\text { Védónók } \\
\mathrm{n}=201\end{array}$ \\
\hline 1. Észak-Magyarország & 13 & 50 & 36 \\
2. Észak-Alföld & 27 & 49 & 18 \\
3. Dél-Alföld & 29 & 60 & 32 \\
4. Közép-Magyarország & 66 & 92 & 53 \\
5. Közép-Dunántúl & 20 & 23 & 14 \\
6. Nyugat-Dunántúl & 22 & 48 & 19 \\
7. Dél-Dunántúl & 13 & 53 & 29 \\
\hline
\end{tabular}


vetett bizalom emelése, illetve a vakcinák pozitív előny/ kockázati arányának hangsúlyozása. Az orvosok 2/3-a nagyobb hangsúlyt fektetne az NNK módszertani levelében felsorolt kötelező vagy ajánlott oltások értékeinek tudatosítására, az átoltottság növelésének fontosságára. $A$ védőnők körében lényegesen alacsonyabb ez az arány, mindössze $40 \%$. Ez akár arra is utalhatna, hogy a védónők gyakran kapnak iránymutatást a járványügyi szervektől, de a kutatás során feltárt további tényező́k fényében inkább arra következtetünk, hogy ez annak a következménye, hogy mindennapi területi munkavégzésük során kevesebb alkalmuk van szakmai eszmecserére más védőnőkkel, így kevésbé jut tudomásukra, ha azok esetleg nem értenek velük egyet. A járványügyi szervek által kiadott irányelveknek, módszertani ajánlásoknak kitüntetett szerepük van a szakemberek tájékoztatásában, szakmai tevékenységük hitelességének megalapozásában $[9,10]$.

A védőoltások hatásosságának megitélésében fontos szempont a védőoltással elérhető átoltottság és a nem oltottak védelme (nyájvédelem, nyájimmunitás) [11], ezért ennek megjelenését is vizsgáltuk. Mindhárom vizsgált csoportban nagyon alacsony azon szakemberek aránya, akik soha nem tájékoztatják az oltások össztársadalmi jelentőségéről az érintetteket. A védőnők kiemelkedően magas arányban (79\%) tájékoztatják a szülőket a nyájimmunitás jelentőségéről a kötelező védőoltások kapcsán, ám csupán 40\%-uk tesz így az összes ajánlott védőoltás esetében is. A gyermekorvosoknál a nyájvédelem fontossága leginkább az influenza, a Meningococcus és a varicella elleni oltások kapcsán szerepelt az érvelésben. Érdekes különbség, hogy míg az orvosok a legnagyobb arányban ajánlott védőoltásokat említettek, addig a védőnők az oltásellenesek által a legrégebben támadott MMR-t, aminek hátterében az Európában egyre növekvő számú kanyarómegbetegedés állhat [12].

Az oltásokra vonatkozó tudományos bizonyitékokkal kapcsolatos kételyekre következtethetünk abból, hogy milyen kétségeket, szakmai vitákat említettek, amikor azt kérdeztük, hogy nekik maguknak milyen aggályaik vannak oltásokkal kapcsolatban, illetve hogy kollégáikkal voltak-e szakmai nézeteltéréseik oltások kapcsán. Felmérésünkben alig voltak olyanok, akik maguk a védőoltások ellen érveltek volna - ami nem meglepő, tekintve, hogy a kutatásban önkéntes volt a részvétel, és Magyarországon a kötelező védőoltások kapcsán akár szankcióknak is kiteheti magát, aki elutasítja őket -, de többen beszámoltak arról, hogy érvelniük kellett a védőoltások mellett. A házi gyermekorvosok közel l/4-ének, a háziorvosok 15\%-ának és a védőnők 4\%-ának volt ilyen tapasztalata. Indirekten, de a védőoltásokról rendelkezésre álló tudományos bizonyítékokkal kapcsolatban kétkedésre utalhatnak a védőoltások idôzítésével kapcsolatos viták. Az oltási bizonytalanság jelei közé sorolható, ha halasztják vagy időben széthúzzák az ajánlotthoz képest az oltási időpontokat [8]. Ez a jelenség elsősorban a házi gyermekorvosok gyakorlatában fordult elő.
Adataink szerint a védőnők minden egyes nem kötelező védőoltást szignifikánsan kisebb arányban ajánlanak, mint a házi gyermekorvosok. Ennek értékelésekor figyelembe kell venni, hogy az 'ajánlás' alapvetően az orvosi gyakorlathoz kötődő tevékenység, míg a védőnői munkában a neutrális jellegú tanácsadás szerepel [13]. Van, szerencsére mindössze 3\%-nyi, védőoltások ellen érvelő védônői vélemény is - ez mindenképpen megengedhetetlen.

A válaszadók az oltások biztonságosságával kapcsolatos kételyeket illetôen Karafillakis és mtsai által is említett résztémaköröket vetettek fel: mellékhatások, esetleges mellékhatás jelentkezésekor a búntudat, aggodalom, hogy az új oltásokat talán nem tesztelték kellően hosszú ideig $[7,8]$. Felmérésünkben többeket aggasztanak a ritka mellékhatások, mint azok, amelyek nagyobb eséllyel jelentkeznek mindennapi munkájuk során. Ez megfelel a nemzetközi adatoknak, amelyek igazolták, hogy az egészségügyi szakemberek leginkább a mellékbatások miatti aggodalom miatt nem adják be az oltást [14].

A vizsgálatunkhoz mintaként használt ECDC-kutatásban több résztémakört határoztak meg az oltások előnyeinek kommunikációjával kapcsolatban. Elsóként arra tértek ki, mennyire fontos érdemben reagálni a páciensek/szülő́k felmerülő kérdéseire, reagálni bizonytalanságaikra, „megbízható és pontos információt osztani meg velük olyan módon, hogy az érthető legyen számukra". Másodikként a tájékoztatáshoz használt eszköztárukat írták le, például az egészségügyi szakember fotókat mutathat az adott betegségről; elmondhatja, hogy ő maga is oltja a saját gyermekeit. Vannak olyan vélemények is, hogy csak semleges tényeket és információkat hasznos szolgáltatni a vakcinációról anélkül, hogy megpróbálnák befolyásolni a páciensek álláspontját $[7,8]$. Nemzetközi tapasztalatok szerint a védőoltások „előírása” alacsonyabb hatékonysággal vezet kooperációhoz a szülőkkel, mint a védőoltással kapcsolatos kérdések megválaszolása alapján történő tanácsadás [15]. A megkérdezett szakemberek több mint $2 / 3$-a szerint az egészségügyi dolgozók körében nagyobb hangsúlyt kellene fektetni a páciensek aggályaira koncentráló kommunikációs ismeretekre (házi gyermekorvosok: 76\%, felnőtt- és vegyes praxisban dolgozó háziorvosok, védőnők: 70\%). Az érdeklődő beteg kérdéseire számítani kell, az egészségügyi szakemberek kommunikációs képzési igényeinek kielégítésével lehetôvé válna, hogy az immunizációval összefüggő hatékonysági és biztonságossági adatokon túl, a védőoltásokkal kapcsolatos kommunikáció az adott beteg élethelyzetéhez, szociális állapotához igazodjon [6]. Az iskolaorvosok, tanárok meggyőződése az oltások fontosságáról és az oltással kapcsolatos ismeretek kommunikációja hatással van az iskolai oltásokkal elért átoltottság arányára is [16].

A szakemberek többsége úgy véli, hogy o" maga elegendô információt és tanácsot ad a pácienseknek a védőoltásokkal kapcsolatban. A háziorvosoknak ugyanakkor csak alig több mint a fele gondolja, hogy kollégái elegendő 
időt szánnak a védőoltásokkal kapcsolatos információk átadására és a páciensek kérdéseinek megválaszolására. A Központi Statisztikai Hivatal adatai szerint a háziorvosok száma folyamatosan csökken: 2016-ban 6199 háziorvos dolgozott az országban, az ezredfordulón mértnél 8\%-kal kevesebb. Az egy háziorvoshoz (felnőtt- és vegyes praxis) átlagosan bejelentkezett lakosok száma 4\%kal több 2000 óta, s 2016-ban elérte az 1581 föt [17] - ami oka lehet a páciensek informálására szánt kevesebb időnek.

Az elérhető információs anyagok tekintetében a betegek körében igénybe vett webalapú tájékoztatók használata meghaladja az egészségügyi szakemberek által igénybe vett webalapú használatot. Ez a diszkrepancia jelzi, hogy érdemes lehet az oltásokról a lakosság számára szóló tájékoztatásra fordítható erőforrások egy részét átcsoportosítani online, elektronikus csatornákra. Ugyancsak figyelmeztetésként szólhat a szakemberek felé, hogy hasznos lehet kikérdezni pácienseiket online információs forrásaikról az oltások kapcsán, illetve ajánlani számukra megbízható és közérthető weblapokat.

Karafillakis és mtsai szerint a következő szempontok merülnek fel, amikor az oltások nem ajánlása vagy késleltetése kerül szóba: az oltás alacsony hatékonysága; egyes vakcinák (például az influenza) nem mindig felelnek meg a járványügyi helyzetnek. További fenntartásként jelenhet meg, hogy a gyermekek már így is elég sok oltást kapnak [7, 8]. Adataink szerint a házi gyermekorvosok felének, a háziorvosok 39\%-ának és a védőnők 1/3-ának van olyan kollégája, aki valamelyik ajánlott védőoltás - a leggyakrabban az influenza elleni - beadását nem támogatja. Ez a vélemény összhangban van az egészségügyi szakemberek influenza elleni alacsony átoltottságával is [18].

Kutatásunk szerint a házi gyermekorvosok $1 / 3-a$, a háziorvosok 17\%-a és a védőnők mindössze 11\%-a tartja hitelesnek az orvoslátogatóktól kapott, illetve a vakcinagyártók honlapjairól, hírleveleiből származó információkat. Egy nemzetközi kutatás is számos negatív tényezőt tárt fel az oltásokra vonatkozó információforrások megbízhatóságát illetően. Általános a bizalmatlanság, külön nevesítve a gyógyszergyártókkal és egészségügyi hatóságokkal szembeni bizalmatlanság/bizalom kérdését. A pácienseknek szóló tájékoztatásokról is megoszlottak a vélemények. Vannak, akik a biztonsággal kapcsolatos információk hiányát emelik ki, nem látják biztosítottnak, hogy a betegek tájékozott döntést hozhassanak. Mások elégedettek az oltásokkal kapcsolatos információk mennyiségével és minőségével, amelyeket kapnak vagy átadhatnak szórólapokon, plakátokon, könyvekben vagy weboldalakon keresztül.

Összességében a magyar szakemberek átlagosan minimum 3 információs anyagot használnak munkájuk során. Megbíznak a hatóságban, de eltérő arányban ítélik szükségesnek a hatósági iránymutatás erősítését: a háziorvosok 60\%-a, a védőnőknek viszont csak a 40\%-a.
A különböző döntésbefolyásoló tényezőkről többnyire mint információforrásokról írnak [8].

Külön fontos említeni a páciensek visszajelzéseit az általuk tapasztaltakról (például a védőoltások mellékhatásainak hiánya vagy a vakcinával megelőzhető fertőzések hiánya). A pácienseket befolyásoló tényezők között hangsúlyos szerepe van a médiának mint az egészségügyi szakembereket, a családokat, egyes „celebeket” - mind pozitív fényben, mind negatív módon - bemutató és ezzel befolyásoló információforrásnak $[7,8]$.

A háziorvosok a praxis típusától függetlenül alacsony arányban tartanak feleslegesnek védőoltást, de szerintük van olyan munkatársuk, aki nem támogatja egy vagy több védőoltás beadását. A védőnők esetében éppen fordítva: többen állították, hogy ők maguk nem tartják szükségesnek valamelyik védőoltást, mint ahányan kollégáikkal kapcsolatban jelezték ezt. Korábbi nemzetközi felmérés adatai alátámasztják megfigyelésünket, hogy a vakcináció kérdéskörében a gyermekorvosok inkább támogatják a védőoltásokat, mint más szakorvosok, illetve a háziorvosok [19]. A védőoltásokkal kapcsolatos attitüd meghatározója az adott védöoltással járó elönyök és várható kockázatok megitélése, ami különbözőképpen fordítódik le a gyermekorvosi és a védőnői munkában. Egy, az Egyesült Királyságban végzett felmérés szerint a gyermekorvosok inkább a védőoltással járó előnyökre, míg a védőnők inkább a kockázatok megbeszélésére fordítanak több időt [20].

Az irodalmi adatok szerint a vakcinációval kapcsolatos fenntartások soha nem homogén módon jelennek meg a térképen, sokkal inkább egy adott szúkebb területre lokalizáltan, így bizonyos valós/vélt mellékhatások jelentkezésének környékén vagy antroposzofista iskolák, vallási vagy etnikai kisebbségek vonzáskörzetében [21]. Egy közösség egészségértési szintje ugyancsak fontos meghatározója az adott közösség védőoltási hajlandóságának [22]. Egy korábbi, gyermeket nevelő szülők körében végzett felmérésünk szerint az egészségértés nincs közvetlenül hatással az oltások elfogadására, azonban a védőoltással megelőzhető betegséggel és a védőoltással kapcsolatos tudás és az általános oltási attitüd igen [23].

\section{Következtetés}

Az első hazai kutatás felhívja a figyelmet a kérdőíves felmérésben megkérdezett egészségügyi szakembercsoportok heterogenitására és a védőoltások kommunikációját érintő szakmai programok szervezésének fontosságára. Kutatásunkban megnyugtatóan alacsonynak találtuk a védőoltások előnyeit elutasító egészségügyi szakemberek arányát. Figyelemre méltó ellentmondást találtunk abban, hogy a betegek számára milyen típusú információs anyagok érhetők el, és ezzel szemben milyen típusú információs forrásokról számolnak be aggályaik, kérdéseik felvetésekor. A védőoltásokkal kapcsolatosan kifejezett kommunikációs képzési igényt fejeztek ki az alapellátás- 
ban dolgozók, melyet mind a graduális, mind a posztgraduális képzés során fontos lesz a jövőben figyelembe venni!

Anyagi támogatás: A közlemény megírása anyagi támogatásban nem részesült. A kutatás magyarországi megvalósulását az MSD Pharma Hungary Kft. támogatta.

Szerzôi munkamegosztás: K. E.: A kutatási koncepció kidolgozása, a statisztikai elemzések elkészítése, az eredmények interpretációja. B. A.: A kutatási koncepció kidolgozása, a nemzetközi előzmények ismertetése, az eredmények interpretációja. M. Zs.: Az eredmények interpretációja, orvosszakmai háttér biztosítása. A cikk végleges változatát mindhárom szerző elolvasta és jóváhagyta.

Érdekeltségek: A publikációban szereplő kutatásban egyik szerzőnek sincs érdekeltsége.

\section{Köszönetnyilvánítás}

A szerzők megköszönik a Házi Gyermekorvosok Egyesülete (HGYE), a Magyar Általános Orvosok Tudományos Egyesülete (MAOTE) és a Magyar Védőnők Egyesülete (MAVE) vezetőségének szakmai javaslatait és a felmérés megvalósításának támogatását.

\section{Irodalom}

[1] World Health Organization. Immunization, Vaccines and Biologicals. Improving vaccination demand and addressing hesitancy. WHO, Geneva, 2018. Available from: https://www.who. int/immunization/programmes_systems/vaccine_hesitancy/ en/ [accessed: May 31, 2019].

[2] Ministry of Human Resources. Methodological guidance on vac cine use in 2018. [Az Emberi Erőforrások Minisztériuma módszertani útmutatója a 2018. évi védőoltásokról.] Eü Közl. 2018; $\operatorname{LXVIII(3):~312.~[Hungarian]~}$

[3] Orenstein WA. Assessing the state of vaccine confidence in the United States: recommendations from the National Vaccine Advisory Committee. Approved by the National Vaccine Advisory Committee on June 10, 2015. Public Health Rep. 2015; 130: 573-595.

[4] World Health Organization. Report of the SAGE working group on vaccine hesitancy. WHO, Geneva, 12 November 2014. Available from: http://www.who.int/immunization/sage/meetings/2014/october/SAGE_working_group_revised_report_ vaccine_hesitancy.pdf?ua=1 [accessed: May 31, 2019].

[5] European Centre for Disease Prevention and Control. Communication on immunisation - building trust. ECDC, Stockholm, 2012. Available from: https://ecdc.europa.eu/sites/portal/ files/media/en/publications/Publications/TER-Immunisation-and-trust.pdf [accessed: May 31, 2019].

[6] Larson HJ, Cooper LZ, Eskola J, et al. Addressing the vaccine confidence gap. Lancet 2011; 378: 526-535.

[7] European Centre for Disease Prevention and Control. Vaccine hesitancy among healthcare workers and their patients in Europe. A qualitative study. ECDC, Stockholm, 2015. Available from: https://ecdc.europa.eu/sites/portal/files/media/en/
publications/Publications/vaccine-hesitancy-among-healthcareworkers.pdf [accessed: May 31, 2019].

[8] Karafillakis E, Larson HJ, ADVANCE consortium. The benefit of the doubt or doubts over benefits? A systematic literature review of perceived risks of vaccines in European populations. Vaccin 2017; 35: 4840-4850.

[9] European Centre for Disease Prevention and Control. Let's talk about protection. ECDC, Stockholm, 2016. Available from: https://ecdc.europa.eu/sites/portal/files/media/en/publications/Publications/lets-talk-about-protection-vaccinationguide.pdf [accessed: May 31, 2019].

[10] Paterson P, Meurice F, Stanberry LR, et al. Vaccine hesitancy and healthcare providers. Vaccine 2016; 34: 6700-6706.

[11] Rashid H, Khandaker G, Booy R. Vaccination and herd immunity: what more do we know? Curr Opin Infect Dis. 2012; 25: 243-249.

[12] ECDC. Bi-annual measles and rubella monitoring report, October 2017. ECDC, Stockholm, 2017. Available from: https:// ecdc.europa.eu/en/publications-data/bi-annual-measles-andrubella-monitoring-report-october-2017) [accessed: May 31, 2019].

[13] Attwell K, Wiley KE, Waddington C, et al. Midwives' attitudes, beliefs and concerns about childhood vaccination: a review of the global literature. Vaccine 2018; 36: 6531-6539.

[14] Maconachie M, Lewendon G. Immunising children in primary care in the UK - What are the concerns of principal immunisers? (Special issue: Health promotion and public health across the UK.) Health Educ J. 2004; 63: 40-49.

[15] Brewer NT, Hall ME, Malo TL, et al. Announcements versus conversations to improve HPV vaccination coverage: a randomized trial. Pediatrics 2017; 139: e20161764.

[16] Salmon DA, Moulton LH, Omer SB, et al. Knowledge, attitudes, and beliefs of school nurses and personnel and associations with nonmedical immunization exemptions. Pediatrics 2004; 113: e552-e559.

[17] Hungarian Central Statistical Office. Hungary, 2016. [Központi Statisztikai Hivatal. Magyarország, 2016.] KSH, Budapest, 2016. Available from: http://www.ksh.hu/docs/hun/xftp/ idoszaki/mo/mo2016.pdf [accessed: May 31, 2019]. [Hungarian]

[18] National Center for Epidemiology. Execution of vaccines, 2015. [Országos Epidemiológiai Központ. Védőoltások teljesítése, 2015.] Epinfo 2016; 23: 369-381. Available from: http://epa. oszk.hu/00300/00398/00694/pdf/EPA00398_epinfo_2016_31.pdf [accessed: May 31, 2019]. [Hungarian]

[19] Posfay-Barbe KM, Heininger U, Aebi C, et al. How do physicians immunize their own children? Differences among pediatricians and nonpediatricians. Pediatrics 2005; 116: e623-e633.

[20] Davis TC, Fredrickson DD, Arnold CL, et al. Childhood vaccine risk/benefit communication in private practice office settings: a national survey. Pediatrics 2001; 107: E17.

[21] Dubé E, Gagnon D, Nickels E, et al. Mapping vaccine hesitancy - country-specific characteristics of a global phenomenon. Vaccine 2014; 32: 6649-6654.

[22] Greenfield LS, Page LC, Kay M, et al. Strategies for increasing adolescent immunizations in diverse ethnic communities. J Adolesc Health 2015; 56(5 Suppl): S47-S53.

[23] Kun E, Gács Zs, Benedek A, et al. HPV vaccination and parental health literacy - the winding path leading to vaccination. [A HPV-oltás és a szüloói egészségértés - kanyargós út az oltásig.] Egészségfejlesztés 2017; 58: 55-64. [Hungarian]

(Mészner Zsófia dr., e-mail: zmeszner@gmail.com) 